\title{
Some parametric effects on fermentation of Cyperus esculentus using Saccharomyces cerevisiae
}

\author{
H. Ibrahim ${ }^{1 *}$, B. O. Atolaiye ${ }^{2}$ and M. O. Aremu $^{3}$ \\ ${ }^{1}$ Department of Chemistry, Federal University Lafia, PMB 146, Lafia, Nasarawa State, Nigeria \\ ${ }^{2}$ Department of Chemistry, Nasarawa State University, PMB 1022, Keffi, Nasarawa State, Nigeria \\ ${ }^{3}$ Department of Chemical Sciences, Federal University Wukari, PMB 1020, Taraba State, Nigeria
}

\begin{abstract}
The fermentation of tiger nut (Cyperus esculentus var. sativus) using Saccharomyces cereviseae was carried out under varying temperature: $25{ }^{\circ} \mathrm{C}, 30{ }^{\circ} \mathrm{C}, 35^{\circ} \mathrm{C}, 40{ }^{\circ} \mathrm{C}, 45^{\circ} \mathrm{C}$ and $50{ }^{\circ} \mathrm{C}$ respectively and $\mathrm{pH}$ of 4.0 which changes due to temperature. The fermentation time was 8 hours for all the temperatures. The effect of temperature on the rate of fermentation of juice from tiger nut was determined using the volume of carbon dioxide produced. Fermentation rate was observed to be highest at $40{ }^{\circ} \mathrm{C}$ while the $\mathrm{pH}$ before and after fermentation were $4.10-4.29$ and 3.60 - 3.67 respectively. The concentrations of ethanol produced were $13.35 \mathrm{~g} / \mathrm{L}, 27.45 \mathrm{~g} / \mathrm{L}, 31.16 \mathrm{~g} / \mathrm{L}, 36.35 \mathrm{~g} / \mathrm{L}, 33.39 \mathrm{~g} / \mathrm{L}$ and $28.94 \mathrm{~g} / \mathrm{L}$ at $25{ }^{\circ} \mathrm{C}, 30{ }^{\circ} \mathrm{C}, 35{ }^{\circ} \mathrm{C}, 40{ }^{\circ} \mathrm{C}, 45{ }^{\circ} \mathrm{C}$ and $50{ }^{\circ} \mathrm{C}$ respectively.
\end{abstract}

Keywords: Tiger nut; Fermentation; Saccharomyces cereviseae; Temperature

\section{Introduction}

Tigernut (Cyperus esculentus) is an underutilized and nonconventional crop of the family Cyperaceae which produces rhizomes from the base and tubers that are somewhat spherical. It is commonly known as "earth almond", "chufa", "chew-fa" and "Zulu nuts". It is known in Nigeria as "Ayaya" in Hausa, "Ofio" in Yoruba and "Akiausa" in Igbo where three varieties (black, brown and yellow) are cultivated. Among these, only two varieties, yellow and brown, are readily available in the market. The yellow variety is preferred over others because of its inherent properties like its large size, attractive colour and fleshier nature. The yellow variety also yields more milk, contains lower fat and higher protein and less anti-nutritional factors especially polyphenols (Okafor et al., 2003). Tigernut can be consumed as raw, roasted, dried, baked or made into a refreshing beverage (Cantalejo, 1997). In addition, tigernut is used for making oil, soap, starch and flour.

Harvested fruits may undergo rapid deterioration if proper processing and storage facilities are not provided, especially in the humid tropics where the prevailing environmental conditions accelerate the process of decomposition.
Fermentation in food processing, using yeast and/or bacteria under anaerobic conditions, is a cheap and energy efficient means of preserving perishable raw materials such as pineapple and cashew juices. Although there are several options for preserving fresh fruits, which may include drying, freezing, canning and pickling, many of these are inappropriate for the produce and for use on small-scale in developing countries (Ross et al., 2002). Fermentation is a value addition to the food product.

Studies on fermentation of tropical fruits such as plantain, banana, cola, mango and pineapple for use in the production of wines of comparable quality to conventional grape wines have been on (Amerine et al., 1980; Akingbala et al., 1994; Joshi et al., 2000; Byarugaba-Bazikare, 2008). The need of processing some locally produced agricultural products is becoming increasingly very important as preservation, waste management and economy diversification measure (Adams, 1978; Ribreau-Gayon et al., 2000).

Although many researchers have worked on tiger nut (Eteshola and Oraedu, 1996; Okafor et al., 2003; Belewu and Abodunrin, 2006; Belewu and Belewu, 2007;

*Corresponding author. e-mail: hashimmadina@gmail.com 
Adejuyitan, 2011; Bamishaiyi and Bamishaiyi, 2011), there is little information on the kinetics of fermentation of tiger nut. This study examines the effects of some physical parameters on the rate of fermentation of Cyperus esculentus juice from yellow variety of tiger nut grown in middle belt Nigeria. Saccharomyces cerevisiae was used in the fermentation process. Saccharomyces cerevisiae has been found to be best for fermentation of fruit juices for wine production (Akingbala et al., 1994; Grossmann et al., 1996; Barnett, 1997; Bely et al., 2008).

\section{Materials and methods}

\section{Samples preparation}

Fresh tiger nut (yellow variety) was obtained from the main market in Keffi, Nasarawa State, Nigeria. The samples were sorted and cleaned to remove foreign materials, bad nuts and seeds which may affect the taste and quality of the drink. The good nuts were washed thoroughly in distilled water so as to remove any adhering soil. Figure 1 shows the flow chart for juice preparation from tiger nut. Thus: One kilogram of nut was blended with $2 \mathrm{~L}$ of water to almost a smooth slurry. This was later filtered using muslin cloth with gentle pressure applied to the content so as to facilitate maximum

\section{Tigernitsectection}
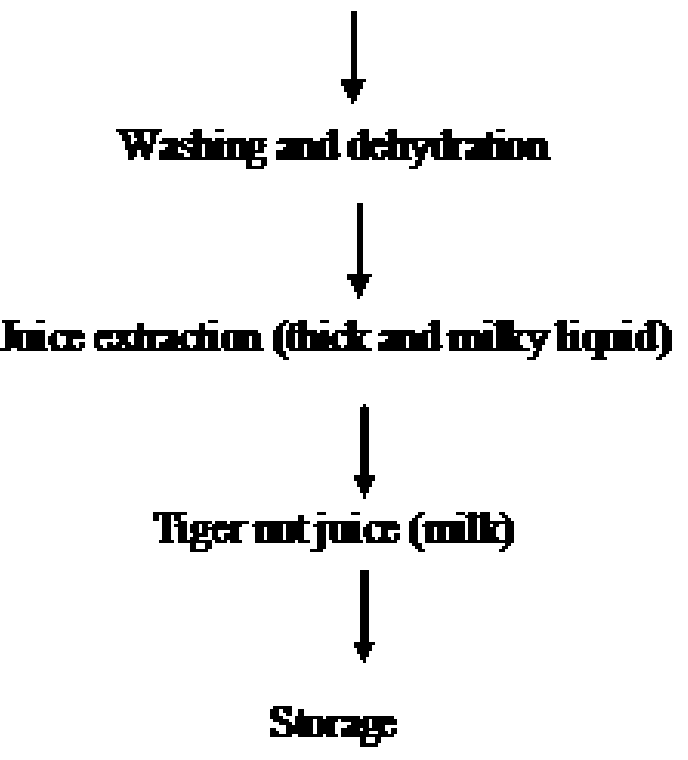

Fig. 1. Flow chart of production process of tiger nut milk liquid extraction. The filtrate was allowed to stand for about 60 min to settle out the starch fraction with subsequent removal of the top liquid portion. The juice sample was filled into jars of capacity 2.5 litres and preserved at $4{ }^{\circ} \mathrm{C}$ to prevent any possible degradation or spoilage during storage.

Baker's yeast

Saf-levure baker's yeast (Saccharomyces cereviseae) manufactured by Lesaffre Group, France was purchased from a local market in Keffi, Nasarawa State.

\section{Fermentation study}

The method of wine preparation described by Akingbala et al. (1994) was adapted. $10.0 \mathrm{~cm}^{3}$ of each juice was taken in a $250 \mathrm{~cm}^{3}$ distillation flask and diluted with $20.0 \mathrm{~cm}^{3}$ of distilled water, to which $2.0 \mathrm{~cm}^{3}$ of ascorbic acid was added. The content (mixture of juice, water and ascorbic acid) was then inoculated with $30.0 \mathrm{~cm}^{3}$ of $20 \%$ (w/v) Saccharomyces cerevisiae which was activated at room temperature in $25 \%$ $(\mathrm{w} / \mathrm{v})$ sucrose solution and was allowed to ferment for 8 hours. The distillation flask was equipped with thermometer, delivery tube and stirrer and was placed in a thermostatic water bath. The $\mathrm{CO}_{2}$ evolved was collected in a standard solution of sodium hydroxide $(0.2 \mathrm{M} \mathrm{NaOH})$ and the solution was titrated with $0.5 \mathrm{M} \mathrm{HCl}$ to get the concentration of $\mathrm{CO}_{2}$ and its volume was used to determine the rate of fermentation. The $\mathrm{pH}$ of the must (content) before and after fermentation was measured using a $\mathrm{pH}$ meter. The study was carried out at $25{ }^{\circ} \mathrm{C}, 30{ }^{\circ} \mathrm{C}, 35{ }^{\circ} \mathrm{C}, 40{ }^{\circ} \mathrm{C}, 45{ }^{\circ} \mathrm{C}$ and $50{ }^{\circ} \mathrm{C}$ respectively.

\section{Results and discussion}

$p H$ variation of must during fermentation.

The $\mathrm{pH}$ values of the tiger nut juice at the fermentation temperatures of $25{ }^{\circ} \mathrm{C}, 30{ }^{\circ} \mathrm{C}, 35{ }^{\circ} \mathrm{C}, 40{ }^{\circ} \mathrm{C} 45{ }^{\circ} \mathrm{C}$ and $50{ }^{\circ} \mathrm{C}$ respectively, before and after fermentation are given in Table 1. The results show that the $\mathrm{pH}$ of the must at all temperatures before fermentation ranged from $4.10-4.29$. The $\mathrm{pH}$ values of the must at the end of fermentation were 3.67, 3.62, $3.69,3.60,3.65$ and 3.64. Table I shows that $\mathrm{pH}$ of must 
decreased after fermentation for each temperature by a factor ranging from 0.40 to 0.69 .

Table I. pH variation of must during fermentation of tiger nut juice

\begin{tabular}{lcc}
\hline $\begin{array}{l}\text { Fermentation } \\
\text { temperature }{ }^{\circ} \mathrm{C}\end{array}$ & $\begin{array}{c}\text { Must } \mathrm{pH} \text { before } \\
\text { fermentation }\end{array}$ & $\begin{array}{c}\text { Must } \mathrm{pH} \text { after } \\
\text { fermetation }\end{array}$ \\
\hline 25 & 4.10 & 3.67 \\
30 & 4.12 & 3.62 \\
35 & 4.25 & 3.69 \\
40 & 4.29 & 3.60 \\
45 & 4.21 & 3.65 \\
50 & 4.22 & 3.64 \\
\hline
\end{tabular}

Improved ethanol fermentation activity can be achieved by controlling various parameters. In addition to temperature and substrate concentration, $\mathrm{pH}$ is also a key factor that affects ethanol fermentation (Kasemet and Nisamedtinov, 2007). To determine the variation of $\mathrm{pH}$ in the must during fermentation, the $\mathrm{pH}$ value of the juices were measured before and after fermentation at different working temperatures.
The $\mathrm{pH}$ range obtained from the results above agrees with the favourable $\mathrm{pH}$ range (3.75 to 4.35 ) reported by earlier researchers for Saccharomyces cerevisiae (Akingbala et al., 1994, Byarugaba-Bazikare, 2008, Dawodu et al., 2012) (for mango, banana and pineapple respectively). The lower $\mathrm{pH}$ value at the end of fermentation is expected due to ethanol production, dissolved carbon dioxide gas and other by-products of fermentation (Boulton et al., 1996 and Joshi et al., 2000). The $\mathrm{pH}$ has a significant influence on fermentation due to its effect on yeast growth, fermentation rate and by product formation. Therefore maintenance of $\mathrm{pH}$ is of paramount importance in fermentation processes.

\section{Effect of temperature on the fermentation process}

Figure 2 shows the plots of volume of carbon dioxide produced (which determines the fermentation rate) against time at the varying fermentation temperatures: $25^{\circ} \mathrm{C}, 30^{\circ} \mathrm{C}$, $35{ }^{\circ} \mathrm{C}, 40{ }^{\circ} \mathrm{C}, 45^{\circ} \mathrm{C}$ and $50{ }^{\circ} \mathrm{C}$ for tiger nut juice.

Plot A shows that the volume of carbon dioxide increased steadily with time and became constant between 5 and 8

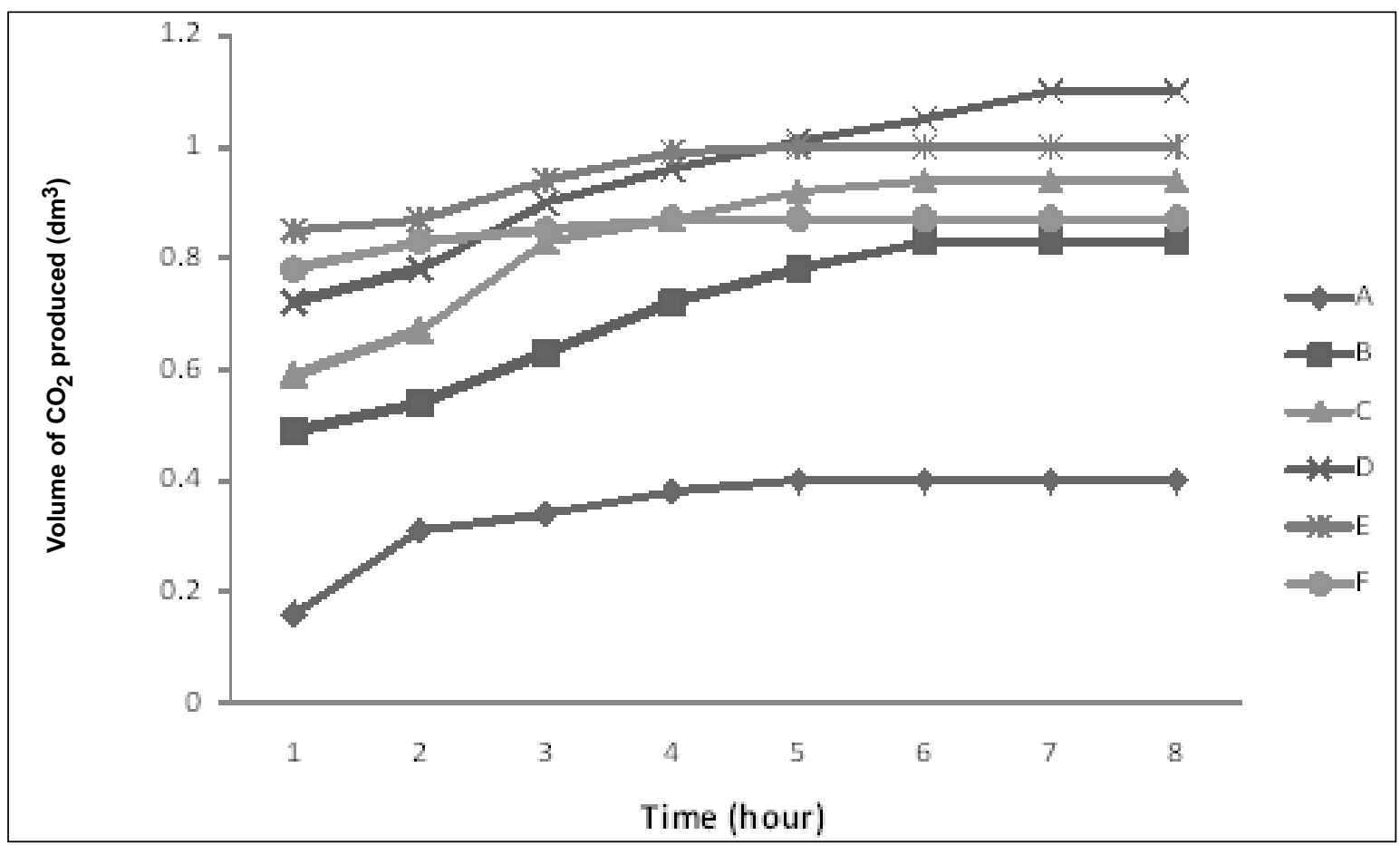

Fig. 2. Effect of temperature on fermentation of tiger nut juice at $25,30,35,40,45$, and $50^{\circ} \mathrm{C}$ respectively 
hours $\left(0.47 \mathrm{dm}^{3}\right)$ showing that at $25^{\circ} \mathrm{C}$, the fermentation of tigernut juice was complete at 5 hours. Between $30{ }^{\circ} \mathrm{C}$ and $35^{\circ} \mathrm{C}$ (plots $\mathrm{B} \& \mathrm{C}$ ), fermentation rate increased and consequently ended or stopped at 6 hours, $\left(30{ }^{\circ} \mathrm{C} ; 0.83 \mathrm{dm}^{3}\right.$ and 35 ${ }^{\circ} \mathrm{C} ; 0.94 \mathrm{dm}^{3}$ ) while at $40{ }^{\circ} \mathrm{C}$ (plot $\left.\mathrm{D}\right)$, the fermentation process was complete at 7 hours $\left(1.10 \mathrm{dm}^{3}\right)$. At $45{ }^{\circ} \mathrm{C}$ (plot E) and $50{ }^{\circ} \mathrm{C}$ (plot $\mathrm{F}$ ), the rate of fermentation stopped at 5 $\left(1.01 \mathrm{dm}^{3}\right)$ and $4\left(0.87 \mathrm{dm}^{3}\right)$ hours respectively. was observed to be higher at high temperatures $35^{\circ} \mathrm{C}$ and 40 ${ }^{\circ} \mathrm{C}$, being highest at $40{ }^{\circ} \mathrm{C}$ for the Cyperus esculentus juice.

\section{Effect of temperature on ethanol yield}

Ethanol production gradually increased during fermentation temperature of 25 to $40{ }^{\circ} \mathrm{C}$ before declining at 45 and $50{ }^{\circ} \mathrm{C}$. At $25{ }^{\circ} \mathrm{C}$ ethanol production was $13.35 \mathrm{~g} / \mathrm{L}$, at $30{ }^{\circ} \mathrm{C}$,

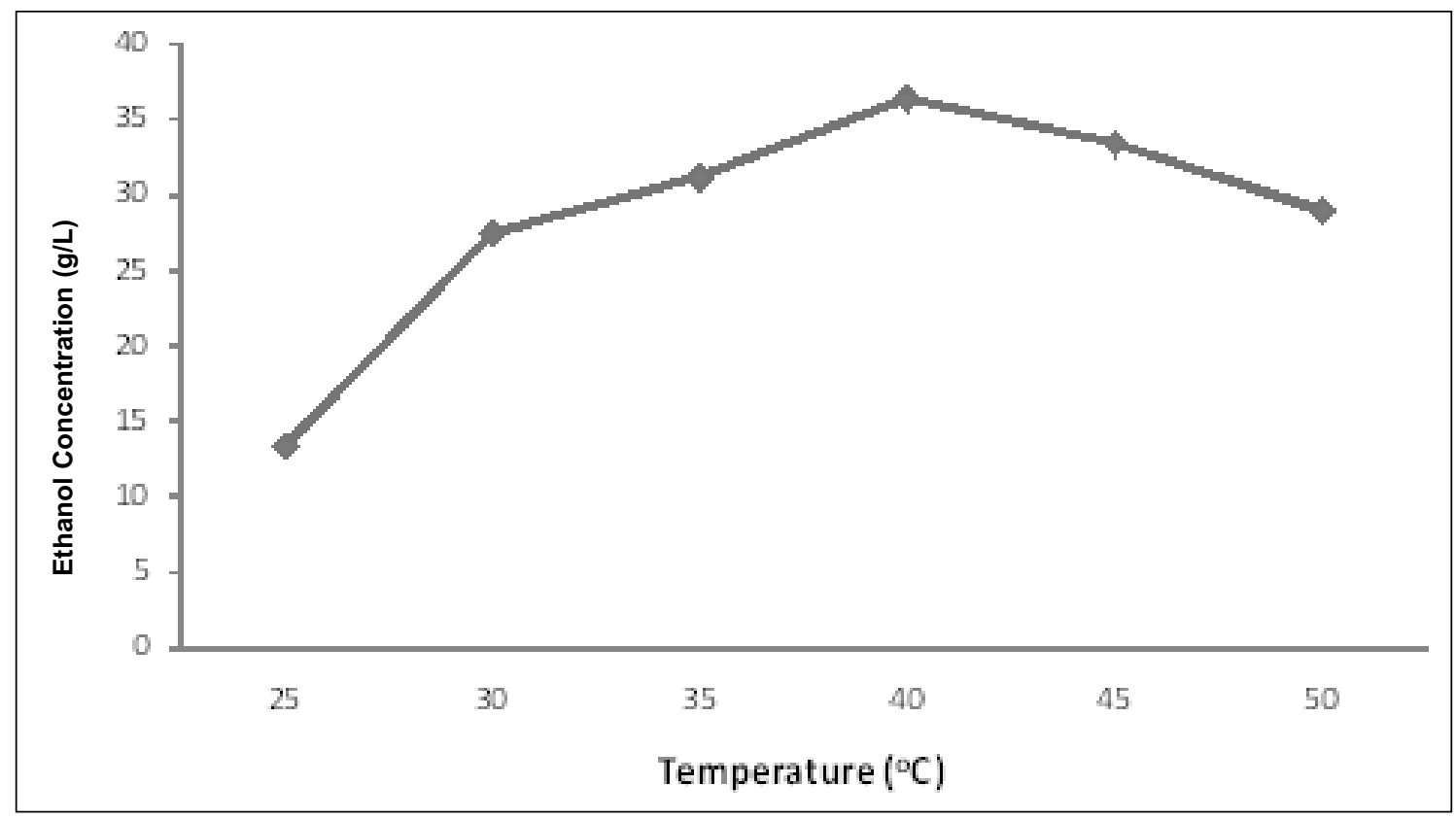

Fig. 3. Effect of temperature on ethanol yield for the fermentation of tiger nut juice

Temperature has a marked influence on the fermentation processes. Usually, the rate of alcoholic fermentation increases with temperature to an optimum between $30{ }^{\circ} \mathrm{C}$ and $40{ }^{\circ} \mathrm{C}$ using conventional yeast (Pramanik, 2003). However, both optimum and temperature tolerance for group and fermentation are strongly strain dependent (Rousseue et al., 1992). The temperature range $25^{\circ} \mathrm{C}$ to $40{ }^{\circ} \mathrm{C}$ at which the fermentation of tiger nut juice was studied in this work has been reported earlier as the temperature range in which alcoholic fermentation using Saccharomyces cerevisiae is favoured (Akingbala et al., 1994; Panjai et al., 2009, Pramanik, 2003) (for mango, pineapple and toddy respectively). The profile of the fermentation at all the temperatures agrees with the profile of alcoholic fermentation with Saccharomyces cerevisiae reported by earlier researchers (Bely et al., 2008; Barnett, 1997). The rate of fermentation
$27.45 \mathrm{~g} / \mathrm{L}$, at $35^{\circ} \mathrm{C}, 31.16 \mathrm{~g} / \mathrm{L}$, at $40^{\circ} \mathrm{C}, 36.35 \mathrm{~g} / \mathrm{L}$, at $45^{\circ} \mathrm{C}$, $33.39 \mathrm{~g} / \mathrm{L}$ and at $50{ }^{\circ} \mathrm{C}$ it was $28.94 \mathrm{~g} / \mathrm{L}$ for tiger nut juice (figure 3).

The yield of ethanol at various temperatures indicates that the fermentation temperature range $35-40{ }^{\circ} \mathrm{C}$ is the optimum temperature for production of ethanol by the strain Saccharomyces cerevisiae. This result contradict with the study of Yah et al., (2010) who found optimum temperature of ethanol production from corn cobs to be $25^{\circ} \mathrm{C}$, but it is in agreement with the study of Dawodu et al., 2012 (pineapple) and Byarugaba-Bazikare (banana), 2008. This result also indicate that the rate of fermentation of tiger nut juice was increased steadily as the temperature changes/ increase from $25-40{ }^{\circ} \mathrm{C}$ using Saccharomyces cerevisiae. 


\section{Conclusion}

In this study, the rate of fermentation of tiger nut juice was monitored at $25{ }^{\circ} \mathrm{C}, 30{ }^{\circ} \mathrm{C}, 35{ }^{\circ} \mathrm{C}, 40{ }^{\circ} \mathrm{C}, 45^{\circ} \mathrm{C}$ and $50{ }^{\circ} \mathrm{C}$ respectively. Saccharomyces cerevisiae was used in the fermentation process. The rate of fermentation is higher at temperatures of $35{ }^{\circ} \mathrm{C}$ and $40{ }^{\circ} \mathrm{C}$, being highest at $40{ }^{\circ} \mathrm{C}$. The study could also establish that tiger nut which is not optimally utilized could effectively be used for ethanol production through the process of fermentation using yeast. The process with optimized fermentation parameters (temperature, $\mathrm{pH}$ ), described in the study could be used for scaling up of the process to a pilot scale or commercial fermenter level thereby making the process more cost effective. It can also be concluded that fermentation could be used as a measure of processing some of the locally produced agricultural products (tiger nut), as a means of preservation, waste management and economic diversification.

\section{References}

Adams MR (1978), Small scale vinegar production from bananas, Tropical Science, 20: 11 - 19.

Adejuyitan JA (2011), Tigernut processing: its food uses and health benefits, American Journal of Food Technology, 6(3): 197- 201.

Akingbala JO, Oguntonehin GB, Olunlade BA and Aina JO (1994), Effects of pasteurization and packaging on properties of wine from over-ripe mango (Mangifera indica) and banana (Musa acuminate) juices, Tropical sciences, 34: 345 - 352.

Amerine MA, Kunkee R, Ough KCS, Singleton VL and Webb AD (1980), The technology of wine making. 4th Ed. (AVI Westport Connecticut) 1980, pp 185-703.

Bamishaiye EI and Bamishaiye OM (2011), Tiger nut: as a plant, its derivatives and benefits, African Journal of Food, Agriculture, Nutrition and Development, 11(5): 5157-5170.

Barnet JA (1997), Sugar utilization by Saccharomyces cerevisiae. In: Yeast sugae metabolism, Zimmermann FK and Enitan KD (eds), (Technomic Publishing Switzerland) 1997, pp 35 - 43.
Belewu MA and Abodunrin OA (2006), Preparation of kunnu from unexploited rich food source: tigernut (Cyperus esculentus), World Journal of Dairy and Food Sciences, 1: 19-21.

Belewu MA and Belewu KY (2007), Comparative physicochemical evaluation of tiger-nut, soybean and coconut milk sources, International Journal of Agriculture and Biology, 9(5): 785-787.

Bely M, Stoeckle P, Maaneuf-Pomarade I and Dubourdieu D (2008), Impact of mixed Torulaspora delbrueckiiSaccharomyces cerevisiae culture media on high sugar fermentation, International J. of Food Microbiology, 122: 169 - 177.

Boulton RB, Singleton VL, Bisson LF and Kunkee RE (1996), Principles and Practices of Winemaking. (Chapman \& Hall, New York) 1996, pp 75 - 221.

Byarugaba-Bazikare GW (2008), Effect of enzymatic processing on banana juice and wine. $\mathrm{PhD}$ Dissertation, $\mathrm{pp}$ 145 - 168, Stellenbosch University, Stellenbosch, Western Cape, South Africa

Cantalejo MJ (1997), Analysis of volatile components derived from raw and roasted earth almond (Cyperus esculentus L.), J. Agric. Food Chem., 45: 1853-1860.

Dawodu MO, Kalu GI and Agboola OA (2012), Fermentation kinetics of Pineapple (Ananas comosus) using yeast (Saccharomyces cerevisiae). Proceedings of the 35th Annual International Conference, Workshop and Exhibition of Chemical Society of Nigeria, 295 - 298.

Eteshola E and Oraedu ACI (1996), Fatty acid composition of tigernut tubers (Cyperus esculentus L.), baobab seeds (Adasonia digitata $\mathrm{L}$.) and their mixture, J. Am. Oil Chem. Soc., 73(2): 255-257.

Grossmann M, Linsenmeyer H, Muno H and Rapp A (1996), Use of oligostrain yeast cultures to increase complexity of wine aroma, Viticultural and Enological Science, 51: 175 - 179.

Joshi VK, Sandhul DK and Thakur NS (2000), Fruit Based Alcoholic Beverages Biotechnolgy: Food Fermentation. Vol. II, Joshi VK and PandeyA (eds) pp. $647-732$. 
Kasemets K and Nisamedtinov I (2007), Growth characteristics of Saccharomyces serevisiae S288C in changing environmental conditions: auxo-accelerostat study, Anton Leeuw, 92: 109 - 128.

Okafor JNC, Mordi JU, Ozumba AU, Solomon HM and Olatunji I (2003), Preliminary studies on the characterization of contaminants in tiger nut (yellow) variety. pp. 210-211, Proceedings of the 27th Annual Conference, 13th- 17th Oct., 2003, Nigerian Institute of Food Science and Technology.

Panjai L, Ongthip K and Chomsri N (2009), Complex fruit wine produced from dual culture fermentation of pineapple juice with Torulaspora delbrueckii and Saccharomyces cereseviae, Asian Journal of Food and Agro-Industry, 2(02): 135-139.

Pramanik K (2003), Parametric studies on batch alcohol fermentation using Saccharomyces yeast extracted from Toddy, J. of Chinese Institude of Chemical Engineers, 34(4): 487 - 492.
Ribéreau-Gayon P, Dubourdieu D, Donèche B and Lonvaud A (2000), The Microbiology of Wine and Vinifications. In: Handbook of Enology. Vol. 1 and 2, (John Wiley and Sons Ltd, England) pp. 255-405.

Ross R, Morgan S and Hill C (2002), Preservation and fermentation: Past, present and future, Int. J. Food Microbiol., 79: 3-16.

Rousseau S, Rouleau D, Yerushalmi L and Mayer RC (1992), Effect of Temperature on Fermentation Kinetics of Waste Sulfite Liquor by Saccharomyces cerevisiae. J. Chem. Tech. Biotechnol., 53: 285.

Yah CS, Iyuke SE, Unuabonah EI, Pillay O, Vishanta C and Tessa SM (2010), Temperature optimization for bioethanol production from corn cobs using mixed yeast strains, J. Biol. Sci., 10: 103 -108.

Received: 13 Ocotober 2015; Revised: 06 December 2015; Accepted: 31 January 2016. 